Article

\title{
Biostimulant Effect of Marine Macroalgae Bioextract on Pepper Grown in Greenhouse
}

\author{
Paulo Melo ${ }^{1,2, *}$, Carlos Abreu ${ }^{3}$, Kiril Bahcevandziev ${ }^{4}$, Glácio Araujo ${ }^{5}$ and Leonel Pereira ${ }^{2}$ (D) \\ 1 Department of Agriculture, Federal University of Lavras/UFLA, Lavras 37200-000, Brazil \\ 2 MARE-Marine and Environment Sciences Centre, Department of Life Sciences (DCV), \\ University of Coimbra, 3000-456 Coimbra, Portugal; leonel.pereira@uc.pt \\ 3 Department of Biology, Federal University of Lavras/UFLA, Lavras 37200-000, Brazil; \\ carlosgodinhoab@gmail.com \\ 4 Agricultural College of Coimbra (ESAC/IPC), Research Centre for Natural Resources Environment and \\ Society (CERNAS), Institute of Applied Research (IIA), 3045-601 Coimbra, Portugal; kiril@esac.pt \\ 5 Ceará Federal Institute/IFCE-Campus Aracati, Aracati 62800-000, Brazil; glacio@ifce.edu.br \\ * Correspondence: pcmelo@ufla.br or paulo.melo@uc.pt; Tel.: +351-910-842-139
}

Received: 21 May 2020; Accepted: 9 June 2020; Published: 11 June 2020

\begin{abstract}
Marine macroalgae are a vast source of raw materials and biologically active molecules used in the pharmaceutical, cosmetic, food and agricultural industries. The search for a food free of chemical residues by consumers has led producers to use environmentally friendly and economically viable products as they are a source of natural compounds, forming a new and promising area of study. In this context, concentrated marine algae extracts (CMAEs) are an important alternative in this production model. This work aimed to evaluate the effects of CMAEs as biostimulants in plant metabolism, promotion of growth, development and production of pepper (Capsicum annuиm L.) cultivated in a greenhouse. This work was carried out from 24 June to 30 October 2019. The number of leaves, plant length, fresh and dry plant mass, root length, root fresh and dry mass, fruit production and the metabolic performance were evaluated. The results of the stomatal conductance of pepper plants, production and biofortification were related with the levels of nutrients absorbed by the plant, which reflected the effect of the applied biostimulant. The dose that showed the most promising results was the $0.5 \%$ concentration of CMAEs.
\end{abstract}

Keywords: macroalgae extracts; rhodophyta; phaeophyceae; biostimulant; pepper

\section{Introduction}

Pepper (Capsicum annuum L.) (Figure 1) is a perennial Solanaceae, grown as an annual crop of great socioeconomic importance [1], and which constitutes one of the five crops with the largest area planted in a protected cultivation system, both in Brazil and in several countries, mainly due to the increase in productivity, fruit quality and for obtaining good market prices when grown in this condition by small and medium producers, being commercialized as green, red, yellow and orange fruit. The largest world pepper producers are Mexico, United States, Italy, Japan, India and Brazil [2].

In Brazil, peppers are one of the 10 most important vegetables for the horticultural market, with a planted area of 13,000 ha and production close to 290,000 tons of fruit per year [3], and are widely exploited, being cultivated throughout the national territory, mainly by small- and medium-sized growers, due to the rapid return on investments, resulting from the short period of production. Analyses carried out by the Brazilian National Health Surveillance Agency (ANVISA, http://portal.anvisa.gov.br/) on sweet pepper since 2001 showed the application of high levels of non-authorized pesticides used to control diseases and insects in this crop. 


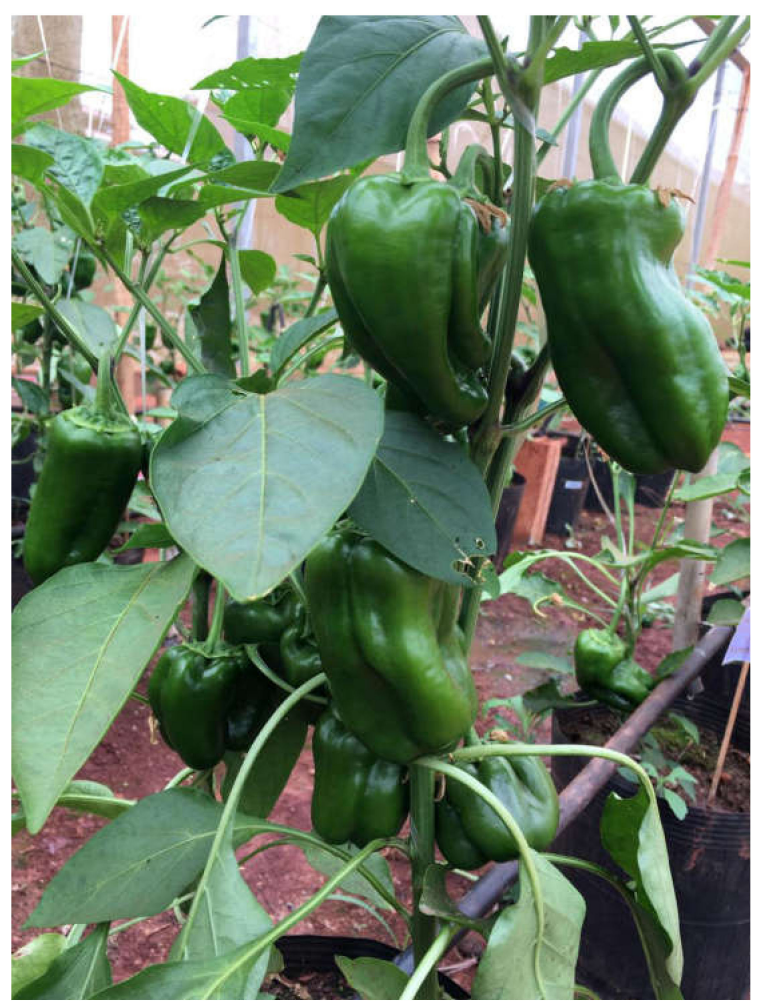

Figure 1. Pepper (Capsicum annuum L.) with fruits.

Considering this relevance and the search for pepper organic production as a viable practice $[4,5]$, it is essential to improve new technologies compatible with this type of production, mainly with the use of substances based on bio products, such as marine macroalgae extracts. The concentrated extracts of marine macroalgae (or seaweeds) are widely used in horticulture, largely because of their growth-promoting effects and tolerance of cultures to abiotic stresses, such as salinity, heat stress, water stress and nutrient deficiency. The chemical constituents of concentrated seaweed extracts include complex polysaccharides, fatty acids, vitamins, phytohormones and mineral nutrients [6]. Recent research has shed light on the possible molecular effects on mechanisms that are activated by seaweed extracts and physiological reactions that these extracts may induce in plants, mainly in horticultural crops [7].

Biostimulants promote plant growth and development throughout the crop cycle, improving the efficiency of plant metabolism, crop quality, and rapid recovery when plants are exposed to abiotic and biotic stresses. Bio-extracts of marine macroalgae act as biostimulants for plants, these effects being attributed to phytohormones, or plant growth regulators, in addition to chemical compounds that can increase tolerance to several biotic and abiotic stresses. Most commercially produced extracts of seaweeds are currently made from brown macroalgae. Polysaccharides extracted from seaweeds are naturally active substances and have important applications as agar, carrageenans and fucoidans that are well known and used in the food, pharmaceutical and biotechnology industries [8]. However, interest in the biotechnological potential of seaweed polysaccharides is recent [9] and in the last few decades the discovery of metabolites with biological activity from macroalgae has increased [10].

The bio-extracts from seaweeds, as they contain phytoregulators, when applied on plants, influence some of the most important pathways in plant metabolism, anabolism and catabolism, such as antioxidant capacity, phenolic levels and flavonoid content. In general, the phytoregulators act on the growth and development of parts or the whole plant, to induce the maintenance of a phenological stage (vegetative phase-growth), or alternate the stage (from the vegetative phase to the reproductive phase-flowering and fruiting) and also to induce rooting (auxins) and new shoots (gibberellins and 
cytokinins) [11], as well as performing photosynthesis, which leads to greater vegetative vigour and, consequently, greater plant growth and development [12].

In this context, we aimed to study the effect of the biostimulant Reabilit ${ }^{\circledR}$ Algas, based on concentrated marine algae extracts (CMAEs), on the pepper plant, its metabolism and fruit production, under controlled conditions.

\section{Materials and Methods}

\subsection{The Trial}

The experiment was conducted in a greenhouse at the Department of Agricultural Engineering of the Federal University of Lavras, located in the municipality of Lavras, MG, Brazil, at $21^{\circ} 12^{\prime} 54^{\prime \prime}$ south latitude and $45^{\circ} 03^{\prime} 16^{\prime \prime}$ west longitude, at $892 \mathrm{~m}$ of altitude. According to the climatic classification of Köppen [13], the regional climate is of the humid subtropical climate type (Cwa), presenting two defined seasons, dry with lower temperatures from April to September, and rainy, with higher temperatures, from October to March [14]. The experiment was carried out between the months of June and October 2019. During the experiment, daily climatological data were collected inside the greenhouse, using a thermo-hygrometer. The maximum and minimum temperatures were recorded in the periods of June, July, August, September and October: 31.7 and $7.4{ }^{\circ} \mathrm{C} ; 29.2$ and $9.1{ }^{\circ} \mathrm{C} ; 32.4$ and $9.3{ }^{\circ} \mathrm{C} ; 31.5$ and $17.5^{\circ} \mathrm{C} ; 36.8$ and $13.1{ }^{\circ} \mathrm{C}$ and air relative humidity of $68 \%, 66 \%, 61 \%, 62 \%$ and $61 \%$, respectively.

The cultivar Elisa (Rogers) pepper (Capsicum annuum L.) plants were grown in $4.5 \mathrm{dm}^{3}$ plastic pots, two plants per pot. Throughout the pepper cycle and up to the pre-harvest, automated irrigation consisted of 4 daily applications, on 10,12, 14 and $16 \mathrm{~h}$ during $6 \mathrm{~min}$, flow rate of $2.0 \mathrm{~L} . \mathrm{h}^{-1}$ drip tips. The substrate water content in the pots was maintained at $60 \%$ of the total pore volume, throughout the experiment. As a base, we used a substrate composed of ravine earth $(60 \%)$, sand $(30 \%)$ and tanned bovine manure $(10 \%)$, with the chemical attributes before the application of treatments, referring to June 2019 (Table 1). (mg/dm³).

Table 1. Chemical content of the substrate before applying the treatments.

\begin{tabular}{|c|c|c|c|c|c|c|c|c|c|}
\hline $\mathrm{pH}^{1}$ & $\mathbf{P}$ & $\mathbf{K}$ & $\mathrm{Zn}$ & $\mathrm{Fe}$ & Mn & $\mathrm{Cu}$ & B & S & P-rem ${ }^{2}$ \\
\hline$\left(\mathrm{H}_{2} \mathrm{O}\right)$ & $\left(\mathrm{mg} / \mathrm{dm}^{3}\right)$ & $\left(\mathrm{mg} / \mathrm{dm}^{3}\right)$ & $\left(\mathrm{mg} / \mathrm{dm}^{3}\right)$ & $\left(\mathrm{mg} / \mathrm{dm}^{3}\right)$ & $\left(\mathrm{mg} / \mathrm{dm}^{3}\right)$ & $\left(\mathrm{mg} / \mathrm{dm}^{3}\right)$ & $\left(\mathrm{mg} / \mathrm{dm}^{3}\right)$ & $\left(\mathrm{mg} / \mathrm{dm}^{3}\right)$ & \\
\hline \multirow[t]{4}{*}{6.3} & 27.02 & 649.07 & 4.24 & 66.28 & 6.62 & 1.74 & 0.04 & 14.5 & 17.45 \\
\hline & $\mathrm{Ca}$ & $\mathrm{Mg}$ & $\mathbf{T}^{3}$ & $\mathrm{~V}^{4}$ & $\mathbf{M}^{5}$ & $\mathbf{O M}^{6}$ & Clay & Silt & Sand \\
\hline & $\left(\mathrm{cmol} / \mathrm{dm}^{3}\right)$ & $\left(\mathrm{cmol} / \mathrm{dm}^{3}\right)$ & $\left(\mathrm{cmol} / \mathrm{dm}^{3}\right)$ & $(\%)$ & $(\%)$ & $(\%)$ & $(\%)$ & $(\%)$ & $(\%)$ \\
\hline & 0.95 & 0.10 & 4.27 & 63.57 & 24.93 & 2.55 & 6.3 & 3 & 55 \\
\hline
\end{tabular}

${ }^{1} \mathrm{pH}$ in $\mathrm{H}_{2} \mathrm{O}$, ratio 1: 2.5, air-dried fine soil (TFSA): $\mathrm{H}_{2} \mathrm{O} ;{ }^{2}$ P-rem = Remaining phosphorus, phosphorus concentration of the equilibration solution after stirring TFSA for $1 \mathrm{~h}$ with $\mathrm{CaCl} 2$ solution containing $60 \mathrm{mg} / \mathrm{L}$ of $\mathrm{P}$, in 1:10 ratio;

${ }^{3} \mathrm{~T}$-CTC (cation exchange capacity): measured at $\mathrm{pH} 7 ;{ }^{4} \mathrm{~V} \%$ (base saturation): proportion of cation exchange occupied by bases $\mathrm{V} \%=[$ Sum of bases $(\mathrm{K}+\mathrm{Ca}+\mathrm{Mg}+\mathrm{Na}) \times 100] / \mathrm{CTC} ;{ }^{5} \mathrm{M}$ (Saturation by $\left.\mathrm{Al} 3+\right) ;{ }^{6} \mathrm{OM}$ (organic matter).

\subsection{Treatments}

The fertilizations were performed, after transplanting the seedlings, according to the plant's demand, a soluble formulation was applied in fertigation: NPK $(8 \%, 11 \%, 38 \%$, respectively $)+1.6 \% \mathrm{Mg}$ $+2.9 \% \mathrm{~S}+0.02 \% \mathrm{~B}+0.04 \%+0.004 \% \mathrm{Cu}+0.2 \% \mathrm{Fe}+0.04 \% \mathrm{Mn}+0.004 \% \mathrm{Mo}+0.02 \% \mathrm{Zn}$, ammonium sulphate, calcium nitrate and potassium chloride.

The mineral content of Reabilit ${ }^{\circledR}$ Algas (Nutrimax Fertilizantes: www.nutrimax.net.br) (Kappaphycus alvarezii-red seaweed and Sargasum vulgare-brown seaweed) was as follows: $3 \% \mathrm{Mg} ; 4 \% \mathrm{~S}$; $3 \% \mathrm{Fe}$ and $0.3 \% \mathrm{~B}$, with additional organic ingredients: CMAEs, amino acids, phytohormones and organic substances that act on the physiological, photosynthetic and nutritional balance of plants. 
Five different treatments (concentrations of Reabilit ${ }^{\circledR}$ Algas) were applied on pepper plants. Plants were divided in 3 blocks with 6 plants each. Treatments applied were: T1-Control (0\%); T2-0.5\%; $\mathrm{T} 3-1.0 \%$; $\mathrm{T} 4-1.5 \%$ and $\mathrm{T} 5-2.0 \%$, in two sprays, the first before flowering, and the second during the fruit formation.

\subsection{Evaluations}

The stomatal conductance (SC) was obtained according to the Ohm's law analogy, through the sum of SC in parallel of the two leaf surfaces, methodology used by Sharpe [15] and Sojka and Parsons [16] referring to the equation:

$$
1 / \mathrm{SC}=1 / \mathrm{CAD}+1 / \mathrm{CAB},
$$

where: SC-stomatal conductance of the culture, $\mathrm{mmol} \mathrm{m}^{-2} \mathrm{~s}^{-1}$; CAD—conductance of the adaxial leaf surface, and $\mathrm{CAB}$ - conductance of the abaxial leaf surface.

The measurements of the culture SC were made using a SC-1 Leaf Porometer with direct SC measurements. The innovative steady-state technology of the SC-1 Leaf Porometer obtaining accurate SC measurements affordable and practical for daily research, determines SC by measuring the vapour flow from the leaf to the environment, determined at 12 o'clock. To determine the agronomic efficiency index (AEI), proposed by Barnes and Kamprath [17], which is calculated by means of the percentage, as relationship between treatments provided by the application of concentrations of the tested product (Reabilit ${ }^{\circledR}$ Algas), subtracting the productivity of the control treatment:

$$
\mathrm{AEI}(\%)=[(\mathrm{Y} 2-\mathrm{Y} 1) /(\mathrm{Y} 1)] \times 100
$$

where $\mathrm{Y} 1$ = Production obtained by the control treatment, in the "zero" dose; $\mathrm{Y} 2$ = Production obtained with the applied doses.

For the physical characteristics, the number of leaves, the fresh and dry mass of the aerial part, the length of the aerial part and the root, the fresh and dry mass of the root, metabolic evaluation (stomatal conductance) and fruit production were evaluated. Longitudinal diameter (LD) measurements were taken at the axis from the base of the peduncle insertion to the fruit apex, and the transverse diameter (TD) measurements were taken on the largest transverse diameter of the fruits, being classified as rectangular in fruits whose longitudinal diameter is greater than the transversal diameter [18].

The chemical characteristics, based on the results obtained in the Foliar Analysis Bulletin of Macronutrient Content, were determined by the accumulation of nutrients in the plants, while the exportation of nutrients was based on the accumulation of nutrients as a function of the dry matter of the aerial part.

\subsection{Statistical Analysis}

The results obtained were submitted to analysis of variance (ANOVA) and Test F, and each pair of means was compared by Tukey's test at $5 \%$ significance, after determining the minimum significant difference. In practical terms, this value gave us an equal margin as the sample sizes were the same, because if the difference between two treatments is greater than that, the averages could be different. For this purpose, the Sisvar computer program was used [19].

\section{Results and Discussion}

The measurements of stomatal conductance began when plants presented 5 pairs of leaves and were made on the adaxial and abaxial faces of leaves of pepper plants (Capsicum annuum L.), located on the upper part of the plant and exposed to solar radiation. Three plants, randomly chosen, were evaluated per treatment. In each plant, a leaf from the top, fully expanded and exposed to solar radiation was selected (Table 2). 
Table 2. Values for number of plants (NP), stomatal conductance (SC) and agronomic efficiency (AE), in relation to control T1, performed in phenological stage: physiological maturation of pepper plants, at $12 \mathrm{~h}$.

\begin{tabular}{|c|c|c|c|}
\hline Treatment & NP & $\mathrm{mmol} \mathrm{m}^{-2} \mathrm{~s}^{-1}$ & AE (\%) in Relation to T1 \\
\hline T1-Control & 3 & 321.4 & 00 \\
\hline T2-Reabilit ${ }^{\circledR}$ Algas $0.5 \%$ & 3 & 408.0 & 27 \\
\hline T3-Reabilit ${ }^{\circledR}$ Algas 1.0\% & 3 & 361.2 & 12 \\
\hline T4-Reabilit ${ }^{\circledR}$ Algas 1.5\% & 3 & 332.9 & 04 \\
\hline T5-Reabilit ${ }^{\circledR}$ Algas $2.0 \%$ & 3 & 385.0 & 20 \\
\hline
\end{tabular}

Values of SC varied from 408 (T2) to 321.4 (T1). The highest AE value was observed in plants treated with T2, with AE 27\% higher than Control.

As the availability of water in the soil decreases, the rate of transpiration decreases as a result of stomata closure. This is one of the important defense mechanisms that plants have against exaggerated water losses, and eventual death due to desiccation [20]. One of the main responses of plants to water deficit is the closure of stomata and, thus, the decrease in $\mathrm{CO}_{2}$ in the leaf mesophyll, which causes the fall of photosynthesis. This allows physiological evaluations, such as gas exchange measures, to be used to assess the effects of water deficiency on plants [21].

According to Oliveira et al. [22], the stomata opening is conditioned by the plant water availability. When there is a water deficiency in the soil, caused by the increase in temperature, there may also be a decrease in photosynthesis. Farias et al. [23] demonstrated that, inside greenhouses, a diffuse solar radiation can, on average, be $65 \%$ higher than outside the greenhouse. In our study, temperatures inside the greenhouse in August reached maximum daily temperatures varying from $26.4{ }^{\circ} \mathrm{C}$ to $32.4{ }^{\circ} \mathrm{C}$, which theoretically can lead to stomatal closure, caused by water deficit, thus decreasing the photosynthesis which conditioned fruit development.

During the entire pepper cycle and until pre-harvest, automated irrigation was applied. However, irrigation is essential for production in a protected environment, requiring a regular supply throughout its cycle [24]. According to Souza et al. [25], for the best development of the pepper plant, the moisture content in the substrate must be kept close to $80 \%$ of the field capacity, during the period from fruiting to harvest. Therefore, both the lack of water in the soil and its excess can reduce crop productivity, even caused by salt excess in the substrate [26].

It can be inferred that the use of the Reabilit ${ }^{\circledR}$ Algas biostimulant provided an increase in agronomic efficiency (AE) in stomatal conductance in the order of $27 \%, 20 \%, 12 \%$ and $4 \%$ in the T2, T5, T3 and T4 treatments, respectively, in comparison with the control. The SC values represented the stomata fully open and favouring respiration due to the absence of water deficit, during all the phenological phases of the pepper culture, the reason for the significant differences found in fruit production (Table 2). Such results may be related to the composition of the biostimulant, which presents biological compounds, such as CMAEs, amino acids, phytohormones and organic substances that assist in the development of the plant and stimulate cell elongation and hormonal balance in the tolerance to water deficit, when applying the lowest concentration of Reabilit ${ }^{\circledR}$ Algas.

\subsection{Physical Characteristics}

After the statistical analysis of the results using the Tukey test for fresh mass of the aerial part in relation to the control treatment T1 it was observed that, with the exception of the treatments T4, T5, the other two treatments presented a statistical difference, $(p<0.05)$, and the T2 treatment showed greater numerical difference (Table 3). These results suggested that the lowest doses of Reabilit ${ }^{\circledR}$ Algas influence heavier production of fresh mass of the aerial part (FMAP) than the higher doses.

The agronomic efficiency index (AEI, \%) was higher with the increase of, the number of leaves, dry mass of aerial part and root, length of aerial part and root, in relation to the control (T1). The T2 treatment (Reabilit ${ }^{\circledR}$ Algas $0.5 \%$ ) presented, in general, highest values of AE in number of leaves (LN, 
$148 \%$ ), fresh mass of the aerial part (FMAP, $127 \%$ ), dry mass of the aerial part (DMAP,113\%) and root dry mass (RDM, 167\%) in relation to the control (Table 3).

Higher fresh mass production in the pepper plants treated with T2 and T3 can probably be a result of the greater plant capacity to synthesize photo-assimilates. These plants showed higher performance of length of the aerial part (LAP), root length (RL), root fresh mass (RFM) and RDM. This can be an indicator that plants which had received lower biostimulant concentrations can be better adapted to water stress conditions $[27,28]$. Therefore, regarding the results of the physical characteristics evaluated in the pepper plants, the use of the Reabilit ${ }^{\circledR}$ Algas, in pepper culture (Capsicum annuum L.) can be highly viable.

The increase in agronomic efficiency in root length, fresh mass and dry root mass, is highlighted by the application of the product Reabilit ${ }^{\circledR}$ Algas versus its absence, which were in the order of $123 \%$ to $230 \%$ for RL, and $94 \%$ to $165 \%$ for RFM, and $25 \%$ to $167 \%$ for RDM. It was observed that the root dry mass in Treatment T2 reached 167\% more in the agronomic efficiency index compared to the Control, which can be inferred that this volume of roots contributed to greater nutrient absorption, reflecting in the total fruit weight, significant after $<0.05$ (Table 4).

As general requirements for commercial production, peppers must have well-defined varietal characteristics, be physiologically developed, well-formed, clean, uniform in colour, free from mechanical and physiological damage, free from pests and diseases and free from substances harmful to health. As their mean longitudinal diameter (LD) was between 82.4 and $96.7 \mathrm{~mm}$ and mean transverse diameter (TD) was between 63, 22 and $51.1 \mathrm{~mm}$ with the $\mathrm{L} / \mathrm{T}$ ratio between 1.4 and 1.76 (Table 4 ). These LD and TD values demonstrate that more than $90 \%$ of the fruits had a tradable size, belonging to Class 8 (www.hortibrasil.org.br accessed in March 2020).

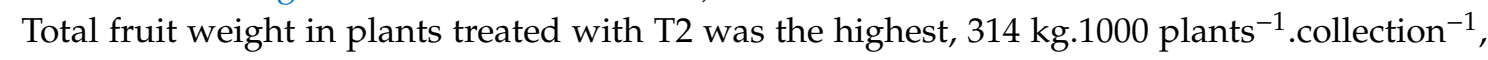
followed by the production in T3 and T5 plants (Table 4).

The values of total fruit mass-TFRM, were significantly different $(p<0.05)$ in treatments T2, T3 and T5, representing an increase in the agronomic efficiency index (69\%,59\% and $44 \%$, respectively) with applications of Reabilit ${ }^{\circledR}$ Algas, compared to the control.

After the analysis of comparison of the means in the Tukey test, for total fruit weight in relation to the control treatment, T1, all treatments showed statistically different results. The T2, T3 and T5 showed greater numerical difference. However, the treatment derived from the $1.5 \%$ dose showed a decrease in this variable, when compared with treatments T2, T3 and T5. This result may suggest that the fruit weight was a function of the fresh mass of the aerial part (Table 4) which was influenced by the production of photo-assimilates resulting from the treatments.

Fontes et al. [29], studied continuous plant growth and verified a greater fruit dry matter in pepper hybrid Elisa grown in a greenhouse. These authors stated that the total production of conventionally grown pepper plants in this type of environment, exceeded $90 \%$ commercially mature fruits during 32 harvests for a period of 8 months. In the T2 and T3 treatments, the estimated number of boxes per 1000 plants was 29 and 27 (11 kg, each), respectively. This was higher production in terms of number of boxes when Reabilit ${ }^{\circledR}$ Algas was used, at any concentration, compared with the control, whose estimate of boxes per 1000 plants was 17. Such results can be explained by the mineral composition of the biostimulant used as a complementary fertilizer. It can be considered that this biostimulant created physiological, photosynthetically and nutritional balance in the plants, promoting an increase of the nutrient concentration in the leaf tissue and directly affecting the fruit production. 
Table 3. Number of leaves (LN), fresh mass of the aerial part (FMAP), dry mass of the aerial part (DMAP), length of the aerial part (LAP), root length (RL), root fresh mass (RFM) and root dry mass (RDM), average of 3 repetitions/treatment and the agronomic efficiency index (AEI, \%) of each evaluated characteristic of the pepper plants.

\begin{tabular}{|c|c|c|c|c|c|c|c|c|c|c|c|c|c|c|}
\hline Treatment & $\begin{array}{c}\text { LN } \\
\text { (Unit) }\end{array}$ & $\begin{array}{c}\text { AE (\%) } \\
\text { LN }\end{array}$ & $\operatorname{FMAP}(g) *$ & $\begin{array}{l}\text { AE (\%) } \\
\text { FMAP }\end{array}$ & $\begin{array}{c}\text { DMAP } \\
\text { (g) }\end{array}$ & $\begin{array}{l}\text { AE (\%) } \\
\text { DMAP }\end{array}$ & $\begin{array}{l}\text { LAP } \\
(\mathrm{cm})\end{array}$ & $\begin{array}{c}\text { AE (\%) } \\
\text { LAP }\end{array}$ & $\begin{array}{c}\mathrm{RL} \\
(\mathrm{cm})\end{array}$ & $\begin{array}{c}\text { AE (\%) } \\
\text { RL }\end{array}$ & $\begin{array}{c}\text { RFM } \\
\text { (g) }\end{array}$ & $\begin{array}{c}\text { AE (\%) } \\
\text { RFM }\end{array}$ & $\begin{array}{c}\text { RDM } \\
\text { (g) }\end{array}$ & $\begin{array}{c}\text { AE (\%) } \\
\text { RDM }\end{array}$ \\
\hline T1 & 39 & 00 & $104 \pm 10.08 c$ & 00 & 15.03 & 00 & 50 & 00 & 13 & 00 & 16 & 00 & 3.0 & 00 \\
\hline T2 & 97 & 148 & $236 \pm 8.01 \mathrm{a}$ & 127 & 32.01 & 113 & 87 & 73 & 33 & 154 & 41 & 156 & 8.0 & 167 \\
\hline T3 & 84 & 115 & $186 \pm 6.54 b$ & 79 & 24.65 & 64 & 89 & 78 & 43 & 230 & 42 & 165 & 7.2 & 140 \\
\hline $\mathrm{T} 4$ & 50 & 28 & $109 \pm 3.51 \mathrm{c}$ & 05 & 16.03 & 07 & 56 & 11 & 29 & 123 & 31 & 94 & 4.4 & 46 \\
\hline T5 & 42 & 08 & $94 \pm 5.68 c$ & -9 & 15.24 & 02 & 62 & 24 & 37 & 185 & 37 & 134 & 3.8 & 25 \\
\hline
\end{tabular}

${ }^{*}$ Averages followed by the same lower-case letter in the FMAP column, do not differ from each other by Tukey test at $5 \%$ probability.

Table 4. Results of longitudinal diameter (LD), transverse diameter (TD), longitudinal vs. transverse ratio (L/T), fruit mass (FRM), average (av.) values per treatment; total fruit mass (TFRM), sum of 6 plants in each treatment; productivity (PROD) and number of boxes (NB), estimate of harvest per 1000 plants and agronomic efficiency index (AEI) of total fruit mass, of 6 pepper plants.

\begin{tabular}{|c|c|c|c|c|c|c|c|c|c|c|c|c|}
\hline Treatment & $\begin{array}{l}\text { LD Max } \\
\text { mm }\end{array}$ & $\begin{array}{l}\text { LD (av.) } \\
\text { mm }\end{array}$ & $\begin{array}{l}\text { LD Min } \\
\text { mm }\end{array}$ & $\begin{array}{c}\text { TD Max } \\
\text { mm }\end{array}$ & $\begin{array}{l}\text { TD (av.) } \\
\text { mm }\end{array}$ & $\begin{array}{l}\text { TD Min } \\
\text { mm }\end{array}$ & $\begin{array}{l}\text { L/T (av.) } \\
\text { Ratio }\end{array}$ & $\begin{array}{l}\text { FRM (av.) } \\
\text { (g) }\end{array}$ & $\begin{array}{c}\text { TFRM } 6 \\
\text { Plants (kg) * }\end{array}$ & $\begin{array}{c}\text { AE TFRM } \\
(\%)\end{array}$ & $\begin{array}{l}\text { Production } 1000 \\
\text { Plants (kg) }\end{array}$ & $\begin{array}{l}\text { NB ** } 1000 \\
\text { Plants }\end{array}$ \\
\hline T1 & 117.3 & 89.7 & 57.6 & 61.8 & 51.1 & 35.0 & 1.76 & 55.80 & $1.2 \pm 9.5 c$ & 00 & 186 & 17 \\
\hline $\mathrm{T} 2$ & 115.5 & 96.6 & 73.0 & 72.7 & 60.0 & 44.9 & 1.60 & 89.69 & $1.9 \pm 4.6 \mathrm{a}$ & 69 & 314 & 29 \\
\hline T3 & 109.3 & 967 & 82.7 & 79.5 & 61.2 & 50.0 & 1.58 & 84.39 & $1.8 \pm 6.5 \mathrm{a}$ & 59 & 295 & 27 \\
\hline T4 & 99.4 & 82.4 & 61.9 & 73.1 & 58.3 & 42.3 & 1.40 & 70.25 & $1.5 \pm 7.3 b$ & 32 & 246 & 22 \\
\hline T5 & 112.3 & 92.5 & 74.1 & 85.3 & 63.2 & 52.4 & 1.46 & 84.43 & $1.6 \pm 6.0 \mathrm{a}$ & 44 & 267 & 24 \\
\hline
\end{tabular}

* Averages followed by the same lowercase letter in the column do not differ by Tukey's test at $5 \%$ probability. ${ }^{*}$ Pepper box $=11 \mathrm{~kg}$. 


\subsection{Chemical Characteristics}

A plant absorbs nutrients through the roots or the leaf surface [30]. Algae extracts can influence physical, biochemical and biological aspects, plant performance and can also affect the architecture of plants and roots, which facilitates efficient absorption of nutrients. Nutrients present in seaweed extracts are easily absorbed by the leaves through stomata and hydrophilic cuticles. The absorption of these mineral nutrients by leaf surface is affected by the conditions of the environment, such as temperature, humidity or light intensity that influence stoma opening, and cuticle and cell wall permeability [31]. Therefore, regarding the results of the physical characteristics in pepper plants (Capsicum annuum L.), the use of Biostimulant Reabilit ${ }^{\circledR}$ Algas can be of high value.

Based on the results obtained in the Foliar Analysis Bulletin of Macronutrient Content (Table 5), the accumulation of nutrients in plants was determined as a function of dry matter of the aerial part-DMAP (see data from Table 3).

The correct nutrient management is a necessary practice for adequate nutrition of the pepper plants and the balanced supply of macro and micronutrients is essential to coordinate absorption of nutrients by the plant [26]. Another aspect to be considered is the specific plant nutrient requirement. It should establish the right amounts of nutrients to be applied as fertilizers in order to lead the best yields [31]. The ideal range of soil $\mathrm{pH}$ for cultivating pepper should be between 5.5 and 6.8 [32]. The value found in our substrate was 6.3 .

The increased macronutrient concentration in the leaf tissue, which resulted from the treatments (Table 5) may be related to better absorption and reuse of these nutrients. This also resulted in the higher production of dry mass of the aerial part-DMAP in kg.1000 plants $^{-1}$, mainly in the T2, T3 and T4 treatments (Table 3).

Regarding the accumulation of nutrients $(\mathrm{N}, \mathrm{Ca}, \mathrm{Mg}, \mathrm{S}, \mathrm{K}$ and $\mathrm{P})$, the order of nutrients absorbed by pepper was observed after application of Reabilit ${ }^{\circledR}$ Algas. When $\mathrm{T} 2$ treatment was applied, the accumulation (AC) of N, P, K, Ca, Mg and S was $240 \%, 100 \%, 159 \%, 191 \%, 182 \%$ and $172 \%$, respectively, higher than nutrient accumulation evidenced by the control. According to Filgueira [33], the main requirements are in order: $\mathrm{K}, \mathrm{Ca}$ and $\mathrm{N}$.

According to the same author [33], the adequate macronutrient content in pepper leaves at the flowering is: $\mathrm{N}$ from 20 to $60 \mathrm{~g} . \mathrm{kg}^{-1}, \mathrm{P}$ from 2.2 to $7.0 \mathrm{~g} \cdot \mathrm{kg}^{-1}, \mathrm{~K}$ from 40 to $60 \mathrm{~g} . \mathrm{kg}^{-1}, \mathrm{Ca}$ from 10 to 25 g.kg ${ }^{-1}, \mathrm{Mg}$ from 3 to $10 \mathrm{~g} . \mathrm{kg}^{-1}$ and S from 4 to $6.2 \mathrm{~g} \cdot \mathrm{kg}^{-1}$. Macronutrient content in our experiment was in the appropriate range for the pepper culture.

In a study with lettuce grown under ideal conditions, it was observed that the application of commercial extract of Eklonia maxima (Phaeophyceae) improved the yield and the concentration of $\mathrm{Ca}$, $\mathrm{K}$ and $\mathrm{Mg}$ in the leaves [34]. Another product based on E. maxima, when applied on the leaf or root of stressed cucumbers, increased the root growth and amounts of $P$ and N [35]. Dobromilska et al. [36] tested a commercial product based on seaweed, via leaf, in tomato culture, which increased the content of mineral nutrients in the following order (N, P, K, Ca, Zn and Fe).

The concentrated extracts of seaweed can provoke a series of beneficial responses in vegetables, such as: improvement of plant vigour, root development, chlorophyll synthesis, promotion of early flowering, fruiting and fruit uniformity, as well as delay in senescence, prolongation of the product's shelf life, improvement of nutritional quality, providing tolerance to water stress, saline and frost, attenuating diseases, promoting tolerance to bacteria and fungi, assisting in pest control, in the control of soil nematodes, and having adjuvant action in mixtures with pesticides [30]. 
Table 5. Values of pepper leaf nutrient content (g.kg ${ }^{-1}$ ). Accumulation (AC) in kg $1000^{-1}$ plants.

\begin{tabular}{|c|c|c|c|c|c|c|c|c|c|c|c|c|}
\hline \multirow[b]{2}{*}{$\begin{array}{c}\text { Treatment/ } \\
\text { DMAP * } \\
(\text { Kg.1000 Plants }\end{array}$} & \multicolumn{2}{|c|}{$\mathbf{N}$} & \multicolumn{2}{|c|}{$\mathbf{P}$} & \multicolumn{2}{|c|}{$\mathbf{K}$} & \multicolumn{2}{|c|}{$\mathrm{Ca}$} & \multicolumn{2}{|c|}{$\mathrm{Mg}$} & \multicolumn{2}{|c|}{$\mathrm{S}$} \\
\hline & g. $\mathrm{kg}^{-1}$ & $\begin{array}{c}\text { AC-N } \\
\text { Kg.1000 } \\
\text { Plants }^{-1}\end{array}$ & g.kg ${ }^{-1}$ & $\begin{array}{c}\text { AC-P } \\
\text { Kg.1000 } \\
\text { Plants }^{-1}\end{array}$ & g. $\mathrm{kg}^{-1}$ & $\begin{array}{c}\text { AC-K } \\
\text { Kg.1000 } \\
\text { Plants }^{-1}\end{array}$ & g. $\mathrm{kg}^{-1}$ & $\begin{array}{l}\text { AC-Ca } \\
\text { Kg.1000 } \\
\text { Plants }^{-1}\end{array}$ & g. $\mathrm{kg}^{-1}$ & $\begin{array}{l}\text { AC-Mg } \\
\text { Kg.1000 } \\
\text { plants }^{-1}\end{array}$ & g. $\mathrm{kg}^{-1}$ & $\begin{array}{c}\text { AC-S } \\
\text { Kg.1000 } \\
\text { plants }^{-1}\end{array}$ \\
\hline $\mathrm{T} 1 / 7.515 \pm 2.6 \mathrm{c}$ & 15.0 & 112.73 & 3.3 & 24.80 & 48.4 & 363.73 & 6.8 & 51.10 & 2.8 & 21.04 & 1.8 & 13.53 \\
\hline $\mathrm{T} 2 / 16.005 \pm 0.4 \mathrm{a}^{* *}$ & 24.0 & 384.12 & 3.1 & 49.61 & 58.8 & 941.09 & 9.3 & 148.85 & 3.7 & 59.22 & 2.3 & 36.81 \\
\hline $\mathrm{T} 3 / 12.325 \pm 1.1 \mathrm{~b}$ & 22.7 & 279.78 & 3.1 & 38.21 & 61.2 & 754.29 & 12.0 & 147.90 & 4.7 & 57.93 & 2.5 & 30.81 \\
\hline $\mathrm{T} 4 / 8.015 \pm 0.23 \mathrm{c}$ & 25.0 & 200.37 & 3.3 & 26.45 & 59.4 & 476.09 & 10.1 & 80.95 & 4.3 & 34.46 & 2.3 & 18.43 \\
\hline $\mathrm{T} 5 / 7.620 \pm 0.51 \mathrm{c}$ & 30.0 & 228.60 & 4.9 & 37.34 & 60.1 & 457.96 & 14.5 & 110.49 & 7.2 & 54.86 & 3.5 & 26.67 \\
\hline
\end{tabular}

${ }^{*}$ DMAP $\left(\mathrm{kg} .1000\right.$ plants $\left.^{-1}\right)=($ DMAP $(\mathrm{g})$ Table. $2 \times 3 \mathrm{rep}) / 6$ plants.treat. $^{-1}{ }^{* *}$ Means followed by the same letter do not differ by Tukey's test at $5 \%$ probability. 


\section{Conclusions}

This work showed that the increase in the concentration of macronutrients in the leaf tissue of pepper plants, as a result of CMAEs application, resulted in higher fruit production.

The stomatal conductance of pepper plants was biostimulated mainly by the application of the $0.5 \%$ concentration of CMAEs. This lowest dose of this product showed better efficiency in all physical and chemical parameters studied.

From our study it was clear that both Kappaphycus alvarezii (Rhodophyta) and Sargassum vulgare (Phaeophycea) can contribute as a biostimulant in plant growth and the production of pepper plants. This can be considered as a promissory treatment and it can be used with other vegetables from the Solanaceous group.

However, further studies are needed to determine the best strategy to adopt. There are a lot of seaweeds (and seaweed combinations) that can be studied, but not all plants respond to their extracts. We hope that data obtained in this work will contribute to the possible use of marine macroalgae extracts in agriculture, making it more environmentally sustainable and economically viable.

Author Contributions: Conceptualization, P.M. and C.A.; methodology, P.M.; software, C.A.; validation, P.M., C.A. and K.B.; investigation, P.M.; resources, P.M. and L.P.; writing-original draft preparation, P.M., K.B and G.A.; writing-review and editing, L.P.; supervision, L.P.; project administration, P.M.; funding acquisition, P.M. All authors have read and agreed to the published version of the manuscript.

Funding: We appreciate the financial support from the company "Nutri Fertilizantes Indústria e Comércio Agropecuário - LTDA. NUTRIMAX. CNPJ: 00.497.089 / 0001-43; Av. Perimetral Norte, Quadra 20 LT $11 \backslash 12$, 7427. Jardim Diamantina, Goiânia - GO, Brazil". Leonel Pereira had the support of Foundation for Science and Technology (FCT), within the scope of the project UIDB/04292/2020 - MARE - Marine and Environmental Sciences Centre.

Conflicts of Interest: The authors declare no conflict of interests.

\section{References}

1. Filgueira, F.A.R. Novo Manual de Olericultura: Agrotecnologia Moderna na Produção e Comercialização de Hortaliças, 3rd ed.; UFV: Viçosa, Brazil, 2013; p. 421. ISBN 978-85-7269-313-4.

2. Roselino, A.C.; Santos, S.A.B.; Bego, L.R. Qualidade dos frutos de pimentão (Capsicum annuum L.) a partir de flores polinizadas por abelhas sem ferrão (Melipona quadrifasciata anthidioides Lepeletier 1836 e Melipona scutellaris Latreille 1811) sob cultivo protegido. R. Bras. Bioci. 2010, 2, 154-158.

3. Marouelli, W.; Silva, W.L.C. Irrigação na Cultura do Pimentão; Ministério da Agricultura, Pecuária e Abastecimento. Circular Técnica 1002, Embrapa: Brasília, Brazil, 2012; p. 24, ISSN 1415-3033.

4. Caruso, G.; Stoleru, V.V.; Munteanu, N.C.; Sellitto, V.M.; Teliban, G.C.; Burducea, M.M.; Tenu, I.; Morano, G.; Butnariu, M. Quality performances of sweet pepper under farming management. Not. Bot. Horti Agrobot. 2019, 47, 458-464. [CrossRef]

5. Caruso, G.; Cozzolino, E.; Cuciniello, A.; Maiello, R.; Cenvinzo, E.; Giordano, M.; De Pascale, S.; Rouphael, Y. Yield and quality of greenhouse organic pepper as affected by shading net in Mediterranean area. Acta Hortic. 2020, 1268, 335-340. [CrossRef]

6. EL Boukhari, M.E.M.; Barakate, M.; Bouhia, Y.; Lyamlouli, K. Trends in seaweed extract based biostimulants: Manufacturing process and beneficial effect on soil-plant systems. Plants 2012, 9, 359. [CrossRef]

7. Battacharyya, D.; Babgohari, M.Z.; Rathor, P.; Prithiviraj, B. Seaweed extracts as biostimulants in horticulture. Sci. Hortic. 2015, 196, 39-48. [CrossRef]

8. Pereira, L. Biological and therapeutic properties of the seaweed polysaccharides. Int. Biol. Rev. 2018, 2, 1-50. [CrossRef]

9. Alves, A.; Sousa, R.A.; Reis, R.L. A practical perspective on ulvan extracted from green algae. J. Appl. Phycol. 2013, 25, 407-424. [CrossRef]

10. Holdt, S.L.; Kraan, S. Bioactive compounds in seaweed: Functional food applications and legislation. J. Appl. Phycol. 2011, 23, 543-597. [CrossRef] 
11. Pereira, L.; Bahcevandziev, K.; Joshi, N.H. Seaweeds as Plant Fertilizer, Agricultural Biostimulants and Animal Fodder, 1st ed.; CRC Press, Taylor \& Francis Group: Boca Raton, FL, USA, 2019; p. 232. ISBN 978-1-13-859706-8. [CrossRef]

12. Melo, P.C.; Abreu, C.A.; Bahcevandziev, K.; Pereira, L. Marine macroalgae bioextract changes the index of reflectance in Pepper plants. Oceanogr. Fish. Open Access J. 2020, 11, 555822. [CrossRef]

13. Barnes, J.S.; Kamprath, E.J. Availability of North Carolina rock phosphate applied to soils. N. C. Agric. Exp. Stn. Tech. Bull. 1975, 229, 23.

14. Sharpe, P.J.H. Adaxial and abaxial stomatal resistance of Cotton in the field. Agron. J. 1973, 65, 570-574. [CrossRef]

15. Sojka, R.E.; Parsons, J.E. Soybean water status and canopy microclimate relationships at four row spacings. Agron. J. 1983, 75, 961-968. [CrossRef]

16. Ferreira, D.F. SISVAR: A computer analisys system to fixed effects split plot type designs. Rev. Bras. Biom. 2019, 37. [CrossRef]

17. Köppen, W. Climatologia: Con un Estudio de los Climas de la Tierra. Fondo de Cultura Economica; Fondo de Cultura Economica: Ciudad de México, Mexico, 1948; p. 478.

18. Dantas, A.A.A.; Carvalho, L.G.d.; Ferreira, E. Classificação e tendências climáticas em Lavras, MG. Cienc. E Agrotecnologia 2007, 31, 1862-1866. [CrossRef]

19. Glenn, D.M.; Scorza, R.; Basset, C. Physiological and morphological traits associated with water use efficiency in the willow-leaf peach. Hortscience 2000, 35, 1241-1243. [CrossRef]

20. Souza, C.R.d.; Soares, Â.M.; Regina, M.d.A. Trocas gasosas de mudas de videira, obtidas por dois porta-enxertos, submetidas à deficiência hídrica. Pesqui. Agropecu. Bras. 2001, 36, 1221-1230. [CrossRef]

21. Oliveira, A.D.; Fernandes, E.J.; Rodrigues, T.d.J.D. Condutância estomática como indicador de estresse hídrico em feijão. Eng. Agríc. Jaboticabal 2005, 1, 86-95. [CrossRef]

22. Farias, J.R.B.; Bergamaschi, H.; Martins, S.R. Berlato, M.A.; Oliveira, A.C.B. Alterações na temperatura e umidade relativa do ar provocadas pelo uso da estufa plástica. Rev. Bras. Agrometeor. Santa Maria 1992, 1, 51-62.

23. Cantuário, F.S. Produção de Pimentão Submetido a Estresse Hídrico e Silicato de Potássio em Cultivo Protegido. Master Thesis, Universidade Federal de Uberlândia, Uberlândia, Brazil, 2012; p. 107.

24. Souza, E.J.; Cunha, F.F.R.; Magalhães, F.F.; Silva, T.R.; Borges, M.C.R.Z.; Roque, C.G. Métodos para estimativa da umidade do solo na capacidade de campo. Rev. De Ciências Agro-Ambient. Alta Floresta 2013, 1, 43-50.

25. Boutraa, T.; Akhkha, A.; Al-Shoaibi, A.A.; Alhejeli, A.M. Effect of water stress on growth and water use efficiency (WUE) of some wheat cultivars (Triticum durum) grown in Saudi Arabia. J. Taibah Univ. Sci. 2010, 3, 39-48. [CrossRef]

26. Amalfitano, C.; Del Vacchio, L.; Somma, S.; Cuciniello, A.; Caruso, G. Effects of cultural cycle and nutrient solution electrical conductivity on plant growth, yield and fruit quality of "Friariello" pepper grown in hydroponics. Hortic. Sci. 2017, 44, 91-98. [CrossRef]

27. Fang, Y.; Du, Y.; Wang, J.; Wu, A.; Qiao, S.; Xu, B.; Zhang, S.; Siddique, K.H.M.; Chen, Y. Moderate drought stress affected root growth and grain yield in old, modern and newly released cultivars of winter wheat. Front. Plant Sci. 2017, 8, 672. [CrossRef] [PubMed]

28. Leme, S.C. Qualidade Pós-Colheita de Pimentões Produzidos em Sistema Orgânico. PhD Thesis, UFLA, Lavras, Brazil, 2012; p. 117.

29. Fontes, P.C.R.; Dias, E.N.; Silva, D.J.H.d. Dinâmica do crescimento, distribuição de matéria seca e produção de pimentão em ambiente protegido. Hortic. Bras. 2005, 23, 94-99. [CrossRef]

30. Silva, M.A.G.d.; Boaretto, A.E.; Melo, A.M.T.d.; Fernandes, H.M.G.; Scivittaro, W.B. Rendimento e qualidade de frutos de pimentão cultivado em ambiente protegido em função do nitrogênio e potássio aplicados em cobertura. Sci. Agric. 1999, 56, 1199-1207. [CrossRef]

31. Craigie, J.S. Seaweed extract stimuli in plant science and agriculture. J. Appl. Phycol. 2011, 23, 371-393. [CrossRef]

32. Faquin, V. Nutrição Mineral de Plantas. In Curso de Pós-Graduação Sensu Lato (Especialização) a Distância: Solos e Meio Ambiente; UFLA: Lavras, Brazil, 2005; p. 186. Available online: http://www.dcs.ufla.br/site/_adm/ upload/file/pdf/Prof_Faquin/Nutricao\%20mineral\%20de\%20plantas.pdf (accessed on 22 May 2020).

33. Filgueira, F.A.R. Solanáceas: Agrotecnologia Moderna na Produção de Tomate, Batata, Pimentão, Pimenta, Beringela e Jiló; UFLA: Lavras, Brazil, 2003; p. 333. ISBN 85-87692-15-1. 
34. Crouch, I.J.; Beckett, R.P.; van Staden, J. Effect of seaweed concentrate on the growth and mineral nutrition of nutrient-stressed lettuce. J. Appl. Phycol. 1990, 2, 269-272. [CrossRef]

35. Nelson, W.R.; Van Staden, J. The effect of seaweed concentrate on growth of nutrient-stressed, greenhouse cucumbers. HortScience 1984, 19, 81-82.

36. Dobromilska, R.; Mikiciuk, M.G.; Gubarewicz, K. Evaluation of cherry tomato yielding and fruit mineral composition after using of Bio-Algeen S-90 preparation. J. Elementol. 2008, 13, 491-499.

(c)

(C) 2020 by the authors. Licensee MDPI, Basel, Switzerland. This article is an open access article distributed under the terms and conditions of the Creative Commons Attribution (CC BY) license (http://creativecommons.org/licenses/by/4.0/). 